\title{
Rapid Inactivation of SARS-CoV-2 Variants by Continuous and Intermittent Irradiation with a Deep-Ultraviolet Light-Emitting Diode (DUV-LED) Device
}

\author{
Hiroko Inagaki $^{1}\left(\mathbb{D}\right.$, Akatsuki Saito $^{2,3,4}{ }^{\mathbb{D}}$, Chiho Kaneko ${ }^{4}$, Hironobu Sugiyama ${ }^{1,5}$, Tamaki Okabayashi ${ }^{2,3,4} 4^{\mathbb{D}}$ \\ and Shouichi Fujimoto ${ }^{6, *(\mathbb{D})}$ \\ 1 M\&N Collaboration Research Laboratory, Department of Medical Environment Innovation, \\ Faculty of Medicine, University of Miyazaki, Miyazaki 889-1692, Japan; \\ hiroko_inagaki@med.miyazaki-u.ac.jp (H.I.); hironobu_sugiyama@med.miyazaki-u.ac.jp (H.S.) \\ 2 Department of Veterinary Science, Faculty of Agriculture, University of Miyazaki, Miyazaki 889-2192, Japan; \\ sakatsuki@cc.miyazaki-u.ac.jp (A.S.); okbys81@cc.miyazaki-u.ac.jp (T.O.) \\ 3 Graduate School of Medicine and Veterinary Medicine, University of Miyazaki, Miyazaki 889-2192, Japan \\ 4 Center for Animal Disease Control, University of Miyazaki, Miyazaki 889-2192, Japan; \\ ckaneko@cc.miyazaki-u.ac.jp \\ 5 Nikkiso Co., Ltd., Tokyo 150-6022, Japan \\ 6 Department of Hemovascular Medicine and Artificial Organs, Faculty of Medicine, University of Miyazaki, \\ Miyazaki 889-1692, Japan \\ * Correspondence: fujimos@med.miyazaki-u.ac.jp; Tel.: +81-985-85-9761
}

\section{check for} updates

Citation: Inagaki, H.; Saito, A.; Kaneko, C.; Sugiyama, H.;

Okabayashi, T.; Fujimoto, S. Rapid Inactivation of SARS-CoV-2 Variants by Continuous and Intermittent Irradiation with a Deep-Ultraviolet Light-Emitting Diode (DUV-LED) Device. Pathogens 2021, 10, 754. https://doi.org/10.3390/ pathogens10060754

Academic Editor: Nicola Coppola

Received: 9 May 2021

Accepted: 11 June 2021

Published: 15 June 2021

Publisher's Note: MDPI stays neutral with regard to jurisdictional claims in published maps and institutional affiliations.

Copyright: (c) 2021 by the authors. Licensee MDPI, Basel, Switzerland. This article is an open access article distributed under the terms and conditions of the Creative Commons Attribution (CC BY) license (https:/ / creativecommons.org/licenses/by/ $4.0 /)$.

\begin{abstract}
More than 1 year has passed since social activities have been restricted due to the spread of severe acute respiratory syndrome coronavirus 2 (SARS-CoV-2). More recently, novel SARS-CoV-2 variants have been spreading around the world, and there is growing concern that they may have higher transmissibility and that the protective efficacy of vaccines may be weaker against them. Immediate measures are needed to reduce human exposure to the virus. In this study, the antiviral efficacy of deep-ultraviolet light-emitting diode (DUV-LED) irradiation $\left(280 \pm 5 \mathrm{~nm}, 3.75 \mathrm{~mW} / \mathrm{cm}^{2}\right)$ against three SARS-CoV-2 variants was evaluated. For the B.1.1.7, B.1.351, and P.1 variant strains, irradiation of the virus stocks for $1 \mathrm{~s}$ resulted in infectious titer reduction rates of $96.3 \%, 94.6 \%$, and $91.9 \%$, respectively, and with irradiation for $5 \mathrm{~s}$, the rates increased to $99.9 \%, 99.9 \%$, and $99.8 \%$, respectively. We also tested the effect of pulsed DUV-LED irradiation $\left(7.5 \mathrm{~mW} / \mathrm{cm}^{2}\right.$, duty rate: $50 \%$, frequency: $1 \mathrm{kHz}$ ) under the same output conditions as for continuous irradiation and found that the antiviral efficacy of pulsed and continuous irradiation was the same. These findings suggest that by further developing and optimizing the DUV-LED device to increase its output, it may be possible to instantly inactivate SARS-CoV-2 with DUV-LED irradiation.
\end{abstract}

Keywords: SARS-CoV-2; variants; UV-LED; viral inactivation; COVID-19

\section{Introduction}

The global severe acute respiratory syndrome coronavirus 2 (SARS-CoV-2) pandemic has placed countries in a difficult and ever-evolving situation for over a year. More than 169 million cases of coronavirus disease (COVID-19) and 3.5 million deaths due to COVID19 have been reported to the World Health Organization (WHO) as of 30 May 2021 [1]; these numbers represent increases of more than approximately 30 - and 10-fold, respectively, when compared to the numbers last year. Although vaccinations have begun around the world, COVID-19 has not yet been completely suppressed. At the end of last year, three variants of SARS-CoV-2, that is, the United Kingdom (UK) strain (B.1.1.7) [2,3], South African strain (B.1.351) [4,5], and Brazilian strain (P.1) [6,7], were confirmed, and they have recently spread all over the world. These variants threaten society as a whole since they may have higher transmissibility [2,3,8-12], the protective efficacy of vaccines may 
be weaker against the variants $[10,13-17]$, and patients infected with the variants may be more likely to develop severe medical conditions [18,19].

However, governments worldwide are attempting to balance economic activity and medical care as much as possible. Although the development of therapeutic agents and vaccines is an important strategy for bringing an end to the pandemic, it is also necessary to devise measures to reduce virus exposure to prevent the spread of infection due to droplets and droplet nuclei.

A deep-ultraviolet light-emitting diode (DUV-LED) instrument that generates around 250- to 300-nm wavelengths has been reported to effectively inactivate microorganisms, including SARS-CoV-2 [20-25]. Although the inactivating effect of DUV-LED irradiation is expected to be similar on wild-type SARS-CoV-2 and the new variants, the effect on the variants has not yet been confirmed, at least not with irradiation at a wavelength of $280 \mathrm{~nm}$. UV-LED devices can emit pulsed irradiation as the radiation can be turned on and off at a high frequency. Recently, pulsed irradiation from UV-LED devices has been shown to be as effective as continuous irradiation for inactivating microorganisms [26]. As pulsed irradiation consumes less energy than continuous irradiation, it may be useful for the development of a more efficient microbe-inactivating device. In this study, we examined whether continuous and intermittent (pulsed) DUV-LED irradiation can inactivate three types of SARS-CoV-2 variants (B.1.1.7, B.1.351, and P.1).

\section{Results}

\subsection{Inactivating Effects of Continuous Irradiation with a DUV-LED Device}

We observed a marked cytopathic effect in all cells that were infected with the UK, South African, or Brazilian strain and not irradiated with DUV-LED light (Figure 1a). The infected cells that were irradiated for $1 \mathrm{~s}$ showed an obvious reduction in the cytopathic effect (Figure 1b), and the morphology of the cells that were irradiated for $5 \mathrm{~s}$ was largely comparable to that of the mock cells (Figure 1c,d).

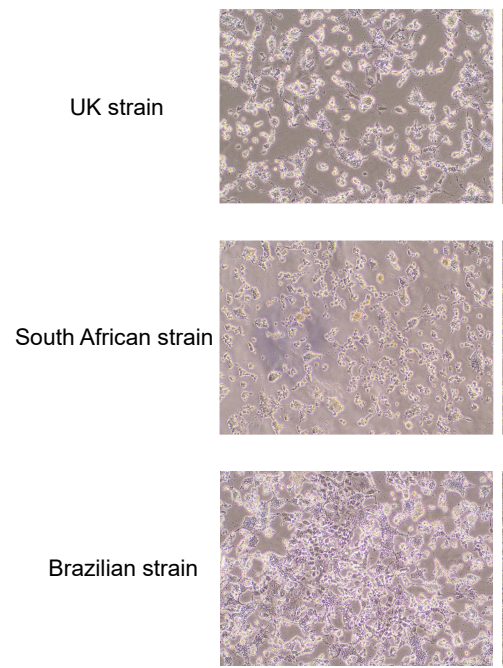

(a) $0 \mathrm{~s}$
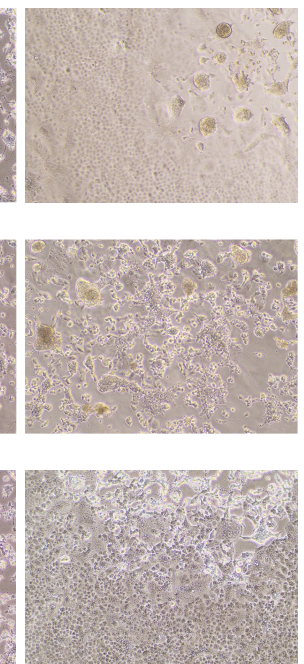

(b) $1 \mathrm{~s}$
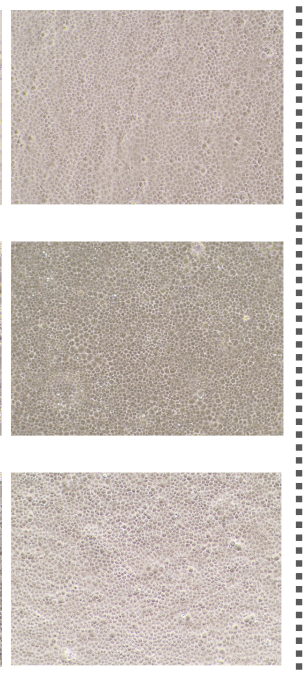

(c) $5 \mathrm{~s}$
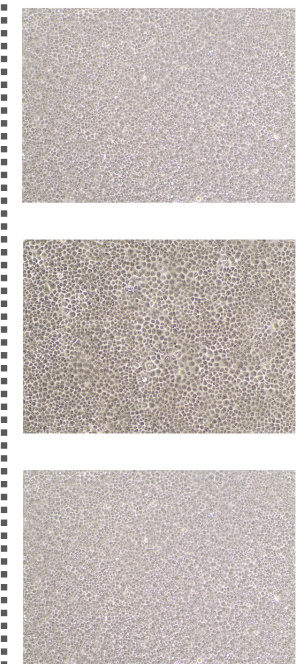

(d) Mock

Figure 1. Cytopathic changes in VeroE6/TMPRSS2 cells. Virus solutions of three types of SARSCoV-2 variants (the UK, South African, and Brazilian strains) were treated with continuous DUVLED irradiation for 0,1 , or $5 \mathrm{~s}$, then diluted 10-fold and inoculated onto VeroE6/TMPRSS2 cells. Representative results are shown. Cytopathic changes in cells infected by virus without irradiation (a), or by virus with irradiation for $1 \mathrm{~s} \mathrm{(b)} \mathrm{or} 5 \mathrm{~s} \mathrm{(c),} \mathrm{which} \mathrm{corresponds} \mathrm{to} 3.75$ or $18.75 \mathrm{~mJ} / \mathrm{cm}^{2}$, respectively. (d) Mock cells.

The plaque assay revealed that a short irradiation time inactivated SARS-CoV-2 variants rapidly (Figure 2). For the virus stocks of the UK, South African, and Brazilian strains, $1 \mathrm{~s}$ of continuous irradiation resulted in infectious titer reduction rates of $96.3 \%, 94.6 \%$, 
and $91.9 \%$, respectively, whereas $5 \mathrm{~s}$ of continuous irradiation resulted in infectious titer reduction rates of $99.9 \%, 99.9 \%$, and $99.8 \%$, respectively (Table 1 and Figure 3 ). These results suggested that continuous DUV-LED irradiation for a very short time can drastically inactivate SARS-CoV-2 variants.

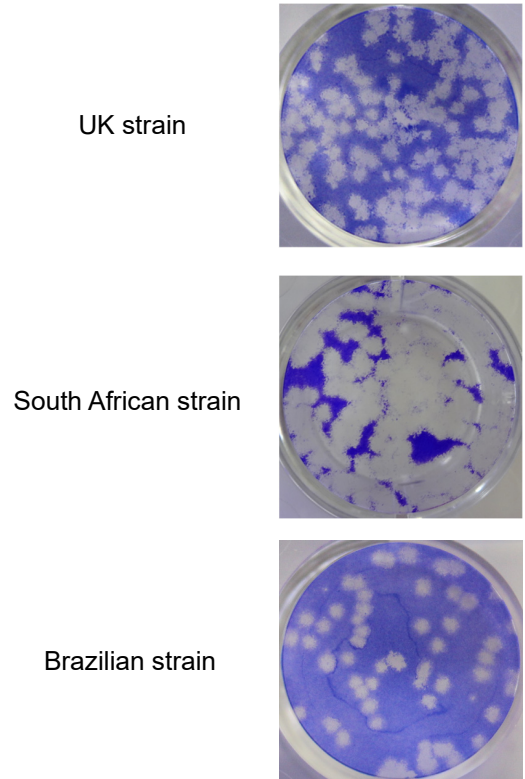

(a) $0 \mathrm{~s}$
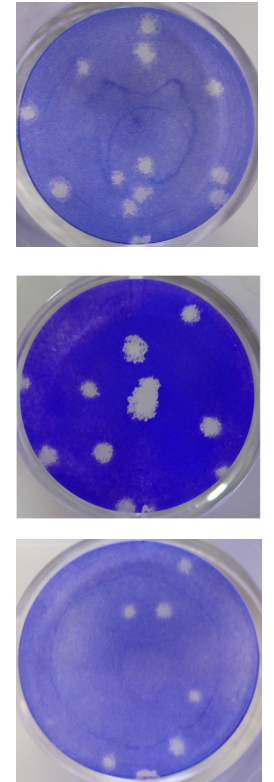

(b) $1 \mathrm{~s}$
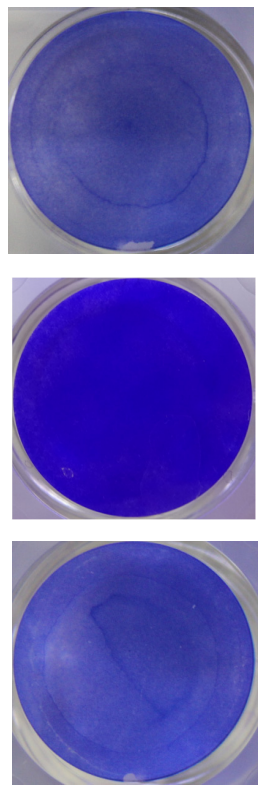

(c) $5 \mathrm{~s}$

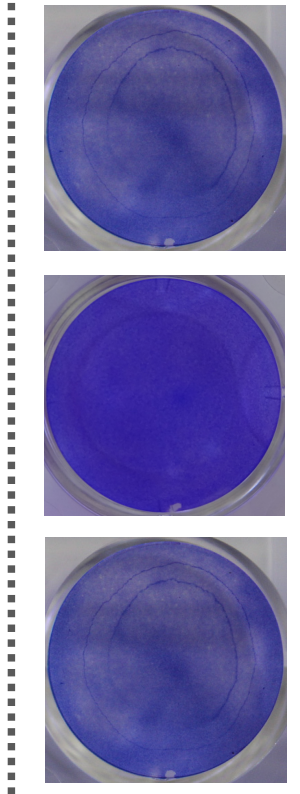

(d) Mock

Figure 2. Plaque formation in VeroE6/TMPRSS2 cells. Virus solutions of three types of SARSCoV-2 variants (the UK, South African, and Brazilian strains) were treated with continuous DUVLED irradiation for 0,1 , or $5 \mathrm{~s}$, then diluted 100-fold and inoculated onto VeroE6/TMPRSS2 cells. Representative results are shown. Plaque formation in cells infected by virus without irradiation (a), or by virus with irradiation for $1 \mathrm{~s} \mathrm{(b)} \mathrm{or} 5 \mathrm{~s} \mathrm{(c),} \mathrm{which} \mathrm{corresponds} \mathrm{to} 3.75$ or $18.75 \mathrm{~mJ} / \mathrm{cm}^{2}$, respectively. (d) Mock cells.

Table 1. Differences in the infectious titer after continuous and pulsed DUV-LED irradiation for the UK, South African, and Brazilian strains irradiated with different patterns of DUV-LED light for 0, 1, 5, or $10 \mathrm{~s}$.

\begin{tabular}{|c|c|c|c|c|c|c|c|c|}
\hline & & \multirow{3}{*}{$\begin{array}{c}\text { Control } \\
\text { (No } \\
\text { Irradiation) }\end{array}$} & \multicolumn{6}{|c|}{ DUV-LED Irradiation Time ( $n=3$, Each) } \\
\hline & & & \multicolumn{2}{|c|}{$1 \mathrm{~s}$} & \multicolumn{2}{|c|}{$5 \mathrm{~s}$} & \multicolumn{2}{|c|}{$10 \mathrm{~s}$} \\
\hline & & & $\begin{array}{l}\text { Continuous } \\
\text { Irradiation }\end{array}$ & $\begin{array}{c}\text { Pulsed } \\
\text { Irradiation }\end{array}$ & $\begin{array}{l}\text { Continuous } \\
\text { Irradiation }\end{array}$ & $\begin{array}{c}\text { Pulsed } \\
\text { Irradiation }\end{array}$ & $\begin{array}{l}\text { Continuous } \\
\text { Irradiation }\end{array}$ & $\begin{array}{c}\text { Pulsed } \\
\text { Irradiation }\end{array}$ \\
\hline \multirow{3}{*}{ UK strain } & PFU (PFU/mL) & $3.5 \times 10^{4}$ & $1.3 \times 10^{3}$ & $1.9 \times 10^{3}$ & $<20$ & $4.0 \times 10^{1}$ & $<20$ & $<20$ \\
\hline & Log PFU ratio ${ }^{a}$ & - & $1.5 \pm 0.4$ & $1.3 \pm 0.1$ & $>3.2$ & $3.0 \pm 0.3$ & $>3.2$ & $>3.2$ \\
\hline & $\begin{array}{c}\text { Infectious titer } \\
\text { reduction rate }{ }^{\mathrm{b}}(\%)\end{array}$ & - & 96.3 & 94.4 & $>99.9$ & 99.9 & $>99.9$ & $>99.9$ \\
\hline \multirow{3}{*}{$\begin{array}{l}\text { South African } \\
\text { strain }\end{array}$} & PFU (PFU/mL) & $5.3 \times 10^{4}$ & $2.9 \times 10^{3}$ & $3.5 \times 10^{3}$ & $<20$ & $5.3 \times 10^{1}$ & $<20$ & $<20$ \\
\hline & Log PFU ratio ${ }^{a}$ & - & $1.3 \pm 0.1$ & $1.2 \pm 0.1$ & $>3.4$ & $3.1 \pm 0.4$ & $>3.4$ & $>3.4$ \\
\hline & $\begin{array}{c}\text { Infectious titer } \\
\text { reduction rate }{ }^{\mathrm{b}}(\%)\end{array}$ & - & 94.6 & 93.4 & $>99.9$ & 99.9 & $>99.9$ & $>99.9$ \\
\hline \multirow{3}{*}{$\begin{array}{l}\text { Brazilian } \\
\text { strain }\end{array}$} & PFU (PFU/mL) & $1.1 \times 10^{4}$ & $8.7 \times 10^{2}$ & $1.7 \times 10^{3}$ & $<20$ & $<20$ & $<20$ & $<20$ \\
\hline & Log PFU ratio ${ }^{a}$ & - & $1.1 \pm 0.3$ & $0.8 \pm 0.0$ & $>2.7$ & $>2.7$ & $>2.7$ & $>2.7$ \\
\hline & $\begin{array}{l}\text { Infectious titer } \\
\text { reduction rate }{ }^{\mathrm{b}}(\%)\end{array}$ & - & 91.9 & 84.4 & $>99.8$ & $>99.8$ & $>99.8$ & $>99.8$ \\
\hline
\end{tabular}

${ }^{a} \log 10(\mathrm{Nt} / \mathrm{N} 0)$ where $\mathrm{Nt}$ is the PFU count of the UV-irradiated sample and N0 is the PFU count of the sample without UV irradiation. Data are shown as mean \pm SD. ${ }^{b}(1-1 / 10 \log$ PFU ratio $) \times 100(\%)$. 
UK strain

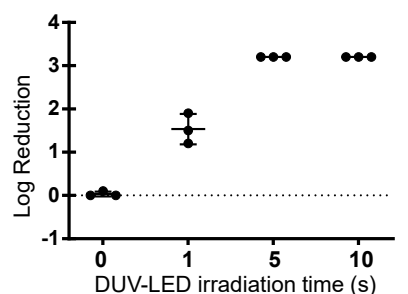

South African strain

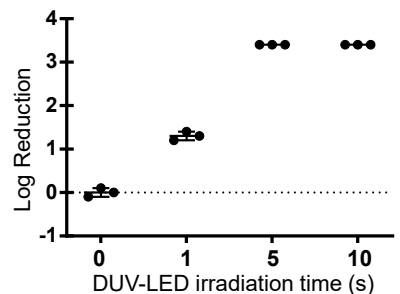

Brazilian strain

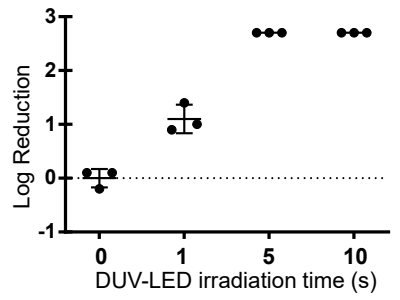

Figure 3. Log reduction in the infectious titer by continuous DUV-LED irradiation (current: $0.35 \mathrm{~A}$ ) for the UK, South African, and Brazilian strains. Time-dependent inactivation of SARS-CoV-2 by irradiation. The results shown are the means and standard deviations of triplicate measurements.

\subsection{Inactivating Effects of Pulsed Irradiation with a DUV-LED Device}

For the virus stocks of the UK, South African, and Brazilian strains, $1 \mathrm{~s}$ of pulsed irradiation resulted in infectious titer reduction rates of $94.4 \%, 93.4 \%$, and $84.4 \%$, respectively, whereas $5 \mathrm{~s}$ of pulsed irradiation resulted in infectious titer reduction rates of $99.9 \%, 99.9 \%$, and $99.8 \%$, respectively (Table 1 and Figure 4). These results were almost the same as those obtained with continuous irradiation.
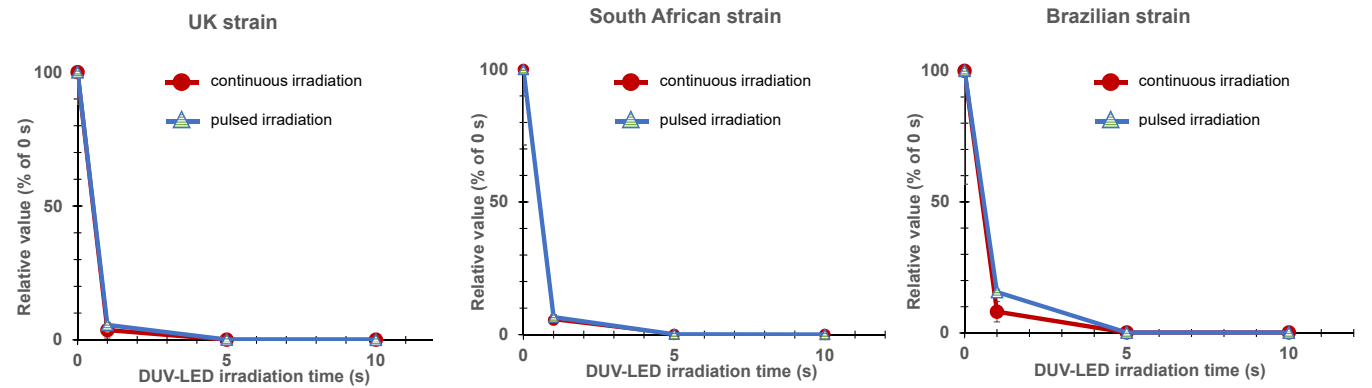

Figure 4. Relative value (percentage of the virus titer of the negative control sample irradiated for $0 \mathrm{~s}$ ) of the infectious titer after continuous (current: $0.35 \mathrm{~A}$ ) or pulsed (current: $0.7 \mathrm{~A}$; duty ratio: 50\%; frequency: $1 \mathrm{kHz}$ ) DUV-LED irradiation for the UK, South African, and Brazilian strains. The inactivating effects were almost the same between the continuous and pulsed irradiation.

\section{Discussion}

The present study demonstrated for the first time that DUV-LED irradiation can rapidly inactivate three types of SARS-CoV-2 variants; that is, the ones that were first described in the UK, South Africa, and Brazil $[2-7,9,10,27]$. Additionally, continuous and pulsed DUV-LED irradiation showed similar degrees of rapid virus inactivation.

UV-LED devices that can provide irradiation at various peak emission wavelengths, such as UV-A (320-400 nm), UV-B (280-320 nm), and UV-C (100-280 nm), have been adopted to inactivate various pathogenic species, including bacteria, viruses, and fungi. UV-C is considered to be the most effective germicidal region of the UV spectrum as it causes the formation of photoproducts in DNA and RNA [28]. These pyrimidine dimers interrupt the transcription, translation, and replication of DNA and RNA, and eventually lead to the death of the microorganism [29]. Last year, we reported for the first time that irradiation with DUV-LED at a wavelength of $280 \pm 5 \mathrm{~nm}$ rapidly inactivated wild-type SARS-CoV-2 that was obtained from a COVID-19 patient [24]. The effect of DUV-LED irradiation on the wild-type SARS-CoV-2 (infectious titer reduction rates of $87.4 \%$ and $99.9 \%$ with $1 \mathrm{~s}$ and $10 \mathrm{~s}$ of irradiation, respectively) was similar to that on the SARS-CoV-2 variants in the present study. Since UV irradiation targets the genomic RNA of SARS-CoV-2 by inducing RNA degradation, the inactivating effects of DUV-LED irradiation on the UK, South African, and Brazilian variants were as expected, and similar effects are also expected for other variants that may emerge in the future. In addition, non-enveloped 
viruses that are highly resistant to disinfectants, including norovirus, are also expected to be susceptible to DUV-LED irradiation (unpublished observations).

In this study, we also tested the effect of pulsed irradiation with a DUV-LED device. As shown in Table 1 and Figure 4, the degree of virus inactivation by continuous and intermittent irradiation was comparable when the device outputs were the same (power $X$ radiation time). This suggested that SARS-CoV-2 may be instantly inactivated by DUVLED irradiation if the DUV-LED device is further developed and optimized to increase its output [26].

Despite the significant inactivating effects of DUV-LED reported here, this study has some limitations. First, these effects may be limited to the test conditions applied in this study, including the irradiation distance and output (working distance of $20 \mathrm{~mm}$; irradiation at $3.75 \mathrm{~mW} / \mathrm{cm}^{2}$ for continuous irradiation and $7.5 \mathrm{~mW} / \mathrm{cm}^{2}$ for pulsed irradiation (duty rate: $50 \%$; frequency: $1 \mathrm{kHz}$ )). The irradiation distance was set to $20 \mathrm{~mm}$, because it was assumed that in practical settings, the irradiation would be performed in a contained device to prevent human exposure. In addition, it is necessary to also evaluate multiple parameters, such as the frequency and duty ratio, to clarify the effectiveness of pulsed irradiation. Additionally, the influence of the material and the power consumption for the high amplitude were not evaluated. In the future, we will examine in more detail whether various conditions of DUV-LED irradiation may affect the degree of the inactivation of microorganisms.

In addition to community settings, healthcare settings are also vulnerable to the invasion and spread of SARS-CoV-2 and its variants. The stability of SARS-CoV-2 in aerosols and on surfaces [30] likely contributes to the transmission of the virus in medical environments. It is important to create an environment that minimizes virus exposure to suppress the spread of SARS-CoV-2 in a sustainable and efficient manner. It was confirmed in our study that SARS-CoV-2, including its variants, is highly susceptible to DUV-LED irradiation. By devising appropriate and optimized irradiation methods, it is conceivable that DUV-LED irradiation can be adapted and applied in various settings. This study provides useful baseline data for securing a safer community and medical environment. The development of devices equipped with DUV-LED is expected to prevent virus spread through the air and from contaminated surfaces.

\section{Materials and Methods}

\subsection{Materials}

1. Cells: VeroE6/TMPRSS2 cells were obtained from the Japanese Collection of Research Bioresources (JCRB) Cell Bank in Japan (https://cellbank.nibiohn.go.jp/english/; JCRB no. JCRB1819. Accessed on 31 May 2021). The cells were cultured in Dulbecco's Modified Eagle Medium (DMEM) containing 10\% fetal bovine serum (FBS), penicillin/streptomycin, and $1 \mathrm{mg} / \mathrm{mL}$ G418 (Thermo Fisher Scientific, Tokyo, Japan).

2. Virus stocks: Three types of SARS-CoV-2 variants, that is, the variants that were first described in the UK (hCoV-19/Japan/QHN001/2020 (B.1.1.7)), South Africa (hCoV19/Japan/TY8-612/2021 (B.1.351)), and Brazil (hCoV-19/Japan/TY7-501/2020 (P.1)), were obtained from the National Institute of Infectious Diseases of Japan. These viruses were propagated in VeroE6/TMPRSS2 cells cultured in DMEM containing 10\% FBS and penicillin/streptomycin. At $48 \mathrm{~h}$ or $72 \mathrm{~h}$ after infection, virus stocks were collected by centrifuging the culture supernatants at $3000 \mathrm{rpm}$ for $10 \mathrm{~min}$. Clarified supernatants were kept at $-80^{\circ} \mathrm{C}$ until use.

3. DUV-LED: The DUV-LED apparatus, which generates a narrow-range wavelength ( $280 \pm 5 \mathrm{~nm})$, was obtained from Nikkiso Co. Ltd. (Tokyo, Japan). This wavelength was selected in consideration of its practicality due to the high output (radiation) power and increased durability of the LED device.

In addition to conventional continuous irradiation, this DUV-LED instrument enables pulsed irradiation as the radiation can be turned on and off at a high frequency. We used a signal generator (AIMEX Corporation, Tokyo, Japan) to irradiate DUV-LED light. 
For the evaluation of DUV-LED inactivation of the target virus, aliquots of virus stock $(150 \mu \mathrm{L})$ adjusted to $5.0 \times 10^{4} \mathrm{PFU} / \mathrm{mL}$ were placed in the center of a $60-\mathrm{mm}$ Petri dish and irradiated with $3.75 \mathrm{~mW} / \mathrm{cm}^{2}$ of continuous irradiation or with $7.5 \mathrm{~mW} / \mathrm{cm}^{2}$ of pulsed irradiation (duty rate: $50 \%$; frequency: $1 \mathrm{kHz}$ ) at a working distance of $20 \mathrm{~mm}$ for various times $(1,5$, or $10 \mathrm{~s} ; n=3$ each). We set the duty rate and frequency of the pulsed irradiation to match the output per time of the continuous irradiation (Supplementary Materials).

\subsection{Methods}

The antiviral efficacy of DUV-LED irradiation against the SARS-CoV-2 variants was evaluated. After DUV-LED irradiation, approximately $120 \mu \mathrm{L}$ of each virus solution (adjusted to $5.0 \times 10^{4} \mathrm{PFU} / \mathrm{mL}$ ) was collected with a $200-\mu \mathrm{L}$ tip. Virus solutions were serially diluted in 10-fold steps in serum-free DMEM in a $1.5 \mathrm{~mL}$ tube, then inoculated onto VeroE6/TMPRSS2 monolayers in a 12-well plate. After the adsorption of virus for $2 \mathrm{~h}$, cells were overlaid with MEM containing 1\% carboxymethyl cellulose and $2 \%$ FBS (final concentration). The cells were incubated for $72 \mathrm{~h}$ in $\mathrm{CO}_{2}$ incubator, then observed under a microscope for cytopathic effects. A non-irradiated virus suspension was used as a negative control. To calculate the PFU, cells were fixed with $10 \%$ formalin for $30 \mathrm{~min}$, and stained with a $2 \%$ crystal violet solution.

The antiviral effects of DUV-LED irradiation were assessed using the logPFU ratio calculated as $\log 10(\mathrm{Nt} / \mathrm{N} 0)$, where Nt is the PFU count of the UV-irradiated sample, and N0 is the PFU count of the sample without UV irradiation. In addition, the infectious titer reduction rate was calculated as $(1-1 / 10 \log$ PFU ratio $) \times 100(\%)$. All experiments were performed in a biosafety level 3 laboratory.

Supplementary Materials: The following are available online at https:/ / www.mdpi.com/article/10 .3390 / pathogens10060754/s1. Scheme S1: Output diagrams of two patterns of DUV-LED irradiation. (A) Continuous irradiation with a current of $0.35 \mathrm{~A}$ for 1, 5, or $10 \mathrm{~s}$. (B) Intermittent (pulsed) irradiation with a current of $0.7 \mathrm{~A}$ for 1,5 , or $10 \mathrm{~s}$ (frequency: $1 \mathrm{kHz}$; duty rate: $50 \%$ ). The output per time was set to be the same between continuous irradiation (A: $3.75 \mathrm{~mW} / \mathrm{cm}^{2} \times$ time) and intermittent irradiation (B: $7.5 \mathrm{~mW} / \mathrm{cm}^{2} \times$ time).

Author Contributions: H.I., H.S. and A.S. conceived the study and wrote the manuscript. A.S., C.K. and T.O. conducted the experiments dealing with the viruses. S.F. contributed to the study design, study supervision, and manuscript revision. All authors have read and agreed to the published version of the manuscript.

Funding: This study was supported in part by the Japan Agency for Medical Research and Development Research Program on Emerging and Re-emerging Infectious Diseases (20fk0108163 and $20 f k 0108518$ to A.S.); Japan Agency for Medical Research and Development Japan Program for Infectious Diseases Research and Infrastructure (20wm0325009 and 21wm0325009 to A.S.); Japan Society for the Promotion of Science (JSPS) KAKENHI Grant-in-Aid for Scientific Research (B) (21H02361 to T.O. and A.S.); JSPS KAKENHI Grant-in-Aid for Scientific Research (C) (19K06382 to A.S.); JSPS KAKENHI Grant-in-Aid for Early-Career Scientists (19K15984 to C.K.); and a Grant for Joint Research Projects of the Research Institute for Microbial Diseases, Osaka University (to T.O. and A.S.).

Institutional Review Board Statement: Not applicable.

Informed Consent Statement: Not applicable.

Acknowledgments: We wish to thank the National Institute of Infectious Diseases, Japan for providing the hCoV-19/Japan/TY7-501/2020, hCoV-19/Japan/TY8-612/2021, and hCoV-19/Japan/QHN001/ 2020 strains.

Conflicts of Interest: H.S. receives part of his salary from Nikkiso Co., Ltd., Tokyo, Japan. Nikkiso Co., Ltd. supplied the deep-ultraviolet light-emitting diode instrument for evaluation. Nikkiso Co., Ltd. had no role in the study design, data collection and analysis, decision to publish, or preparation of the manuscript. The other authors declare no conflicts of interest. 


\section{References}

1. Available online: https://www.who.int/docs/default-source/coronaviruse/situation-reports/20210601_weekly_epi_update_ 42.pdf?sfvrsn=5b0bbc7c_5 (accessed on 31 May 2021).

2. Wise, J. Covid-19: New coronavirus variant is identified in UK. BMJ 2020, 371, m4857. [CrossRef]

3. Volz, E.; Mishra, S.; Chand, M.; Barrett, J.C.; Johnson, R.; Geidelberg, L.; Hinsley, W.R.; Laydon, D.J.; Dabrera, G.; O’Toole, Á.; et al. Assessing transmissibility of SARS-CoV-2 lineage B.1.1.7 in England. Nature 2021, 593, 266-269. [CrossRef]

4. Available online: https:// sacoronavirus.co.za/2020/12/18/new-covid-19-variant-identified-in-sa/ (accessed on 31 May 2021).

5. Tegally, H.; Wilkinson, E.; Giovanetti, M.; Iranzadeh, A.; Fonseca, V.; Giandhari, J.; Doolabh, D.; Pillay, S.; San, E.J.; Msomi, N.; et al. Emergence and rapid spread of a new severe acute respiratory syndrome-related coronavirus 2 (SARS-CoV-2) lineage with multiple spike mutations in South Africa. medRxiv 2020. [CrossRef]

6. $\quad$ Resende, P.C.; Bezerra, J.F.; Vasconcelos, R.H.T.; Arantes, I.; Appolinario, L.; Mendonça, A.C.; Paixao, A.C.; Duarte, A.C.; Silva, T.; Rocha, A.S.; et al. Severe acute respiratory syndrome coronavirus 2 P.2 lineage associated with reinfection case, Brazil, June-October 2020. Emerg. Infect. Dis. 2021, 27. [CrossRef]

7. Faria, N.R.; Mellan, T.A.; Whittaker, C.; Claro, I.M.; Candido, D.D.S.; Mishra, S.; Crispim, M.A.E.; Sales, F.C.; Hawryluk, I.; McCrone, J.T.; et al. Genomics and epidemiology of a novel SARS-CoV-2 lineage in Manaus, Brazil. medRxiv 2021. [CrossRef]

8. Davies, N.G.; Abbott, S.; Barnard, R.C.; Jarvis, C.I.; Kucharski, A.J.; Munday, J.D.; Pearson, C.A.B.; Russell, T.W.; Tully, D.C.; Washburne, A.D.; et al. Estimated transmissibility and impact of SARS-CoV-2 lineage B.1.1.7 in England. Science 2021, 372, eabg3055. [CrossRef]

9. $\quad$ Leung, K.; Shum, M.H.H.; Leung, G.M.; Lam, T.T.Y.; Wu, J.T. Early transmissibility assessment of the N501Y mutant strains of SARS-CoV-2 in the United Kingdom, October to November 2020. Eurosurveillance 2021, 26, 2002106. [CrossRef]

10. Plante, J.A.; Mitchell, B.M.; Plante, K.S.; Debbink, K.; Weaver, S.C.; Menachery, V.D. The variant gambit: COVID-19's next move. Cell Host Microbe 2021, 29, 508-515. [CrossRef]

11. Kissler, S.M.; Fauver, J.R.; Mack, C.; Tail, C.G.; Breban, M.I.; Watkins, A.E.; Samant, R.M.; Anderson, D.J.; Ho, D.D.; Grubaugh, N.D.; et al. Densely sampled viral trajectories suggest longer duration of acute infection with B. 1.1. 7 variant relative to non-B. 1.1. 7 SARS-CoV-2. medRxiv 2021. [CrossRef]

12. Korber, B.; Fischer, W.M.; Gnanakaran, S.; Yoon, H.; Theiler, J.; Abfalterer, W.; Hengartner, N.; Giorgi, E.E.; Bhattacharya, T.; Foley, B.; et al. Tracking Changes in SARS-CoV-2 Spike: Evidence that D614G Increases Infectivity of the COVID-19 Virus. Cell 2020, 182, 812-827. [CrossRef]

13. Madhi, S.A.; Baillie, V.; Cutland, C.L.; Voysey, M.; Koen, A.L.; Fairlie, L.; Padayachee, S.D.; Dheda, K.; Barnabas, S.L.; Bhorat, Q.E.; et al. Efficacy of the ChAdOx1 nCoV-19 Covid-19 Vaccine against the B.1.351 Variant. N. Engl. J. Med. 2021, 384, 1885-1898. [CrossRef]

14. Liu, Z.; VanBlargan, L.A.; Bloyet, L.-M.; Rothlauf, P.W.; Chen, R.E.; Stumpf, S.; Zhao, H.; Errico, J.M.; Theel, E.S.; Liebeskind, M.J.; et al. Identification of SARS-CoV-2 spike mutations that attenuate monoclonal and serum antibody neutralization. Cell Host Microbe 2021, 29, 477-488. [CrossRef]

15. Wang, P.; Casner, R.G.; Nair, M.S.; Wang, M.; Yu, J.; Cerutti, G.; Liu, L.; Kwong, P.D.; Huang, Y.; Shapiro, L.; et al. Increased resistance of SARS-CoV-2 variant P.1 to antibody neutralization. Cell Host Microbe 2021, 29, 747-751. [CrossRef]

16. Weisblum, Y.; Schmidt, F.; Zhang, F.; DaSilva, J.; Poston, D.; Lorenzi, J.C.C.; Muecksch, F.; Rutkowska, M.; Hoffmann, H.-H.; Michailidis, E.; et al. Escape from neutralizing antibodies by SARS-CoV-2 spike protein variants. eLife 2020, 9, e61312. [CrossRef]

17. Hacisuleyman, E.; Hale, C.; Saito, Y.; Blachere, N.E.; Bergh, M.; Conlon, E.G.; Schaefer-Babajew, D.J.; DaSilva, J.; Muecksch, F.; Gaebler, C.; et al. Vaccine Breakthrough Infections with SARS-CoV-2 Variants. N. Engl. J. Med. 2021, 384, 2212-2218. [CrossRef]

18. Davies, N.G.; Jarvis, C.I.; CMMID COVID-19 Working Group; Edmunds, W.J.; Jewell, N.P.; Diaz-Ordaz, K.; Keogh, R.H. Increased mortality in community-tested cases of SARS-CoV-2 lineage B.1.1.7. Nature 2021, 593, 270-274. [CrossRef]

19. Challen, R.; Brooks-Pollock, E.; Read, J.M.; Dyson, L.; Tsaneva-Atanasova, K.; Danon, L. Risk of mortality in patients infected with SARS-CoV-2 variant of concern 202012/1: Matched cohort study. BMJ 2021, 372, n579. [CrossRef]

20. Rattanakul, S.; Oguma, K. Inactivation kinetics and efficiencies of UV-LEDs against Pseudomonas aeruginosa, Legionella pneumophila, and surrogate microorganisms. Water Res. 2018, 130, 31-37. [CrossRef]

21. Nishisaka-Nonaka, R.; Mawatari, K.; Yamamoto, T.; Kojima, M.; Shimohata, T.; Uebanso, T.; Nakahashi, M.; Emoto, T.; Akutagawa, M.; Kinouchi, Y.; et al. Irradiation by ultraviolet light-emitting diodes inactivates influenza a viruses by inhibiting replication and transcription of viral RNA in host cells. J. Photochem. Photobiol. B 2018, 189, 193-200. [CrossRef]

22. Kim, D.-K.; Kang, D.-H. UVC LED irradiation effectively inactivates aerosolized viruses, bacteria, and fungi in a chamber-type air disinfection system. Appl. Environ. Microbiol. 2018, 84, e00944-18. [CrossRef]

23. Cheng, Y.; Chen, H.; Basurto, L.A.S.; Protasenko, V.V.; Bharadwaj, S.; Islam, M.; Moraru, C.I. Inactivation of Listeria and E. coli by Deep-UV LED: Effect of substrate conditions on inactivation kinetics. Sci Rep. 2020, 10, 3411. [CrossRef]

24. Inagaki, H.; Saito, A.; Sugiyama, H.; Okabayashi, T.; Fujimoto, S. Rapid inactivation of SARS-CoV-2 with deep-UV LED irradiation. Emerg. Microbes Infect. 2020, 9, 1744-1747. [CrossRef] [PubMed]

25. Heßling, M.; Hönes, K.; Vatter, P.; Lingenfelder, C. Ultraviolet irradiation doses for coronavirus inactivation-review and analysis of coronavirus photoinactivation studies. GMS Hyg. Infect. Control 2020, 15, Doc08. [PubMed]

26. Song, K.; Taghipour, F.; Mohseni, M. Microorganisms inactivation by continuous and pulsed irradiation of ultraviolet lightemitting diodes (UV-LEDs). Chem. Eng. J. 2018, 343, 362-370. [CrossRef] 
27. European Centre for Disease Prevention and Control. Risk Assessment: Risk Related to Spread of New SARS- CoV-2 Variants of Concern in the EU/EEA. 29 December 2020. Available online: https:/ /www.ecdc.europa.eu/en/publications-data/covid-19 -risk-assessment-spread-new-sars-cov-2-variants-eueea (accessed on 31 May 2021).

28. Bintsis, T.; Litopoulou-Tzanetaki, E.; Robinson, R.K. Existing and potential applications of ultraviolet light in the food industry -A critical review. J. Sci. Food Agric. 2000, 80, 637-645. [CrossRef]

29. Kim, S.-J.; Kim, D.-K.; Kang, D.-H. Using UVC light-emitting diodes at wavelengths of 266 to 279 nanometers to inactivate foodborne pathogens and pasteurize sliced cheese. Appl. Environ. Microbiol. 2016, 82, 11-17. [CrossRef]

30. van Doremalen, N.; Bushmaker, T.; Morris, D.H.; Holbrook, M.G.; Gamble, A.; Williamson, B.N.; Tamin, A.; Harcourt, J.L.; Thornburg, N.J.; Gerber, S.I.; et al. Aerosol and surface stability of SARS-CoV-2 as compared with SARS-CoV-1. N. Engl. J. Med. 2020, 382, 1564-1567. [CrossRef] [PubMed] 